\title{
PENGEMBANGAN BAHAN AJAR AL-QUR'AN HADIS MADRASAH IBTIDAIYAH (MATERI HURUF HIJAIYAH KELAS I SMEMSTER I)
}

\author{
Sigit Purwaka \\ Fakultas Tarbiyah STAIN Al-Fatah \\ J1. Merah Putih Buper Waena Distrik Heram, Kota Jayapura, Papua \\ Email: purwakasigit@gmail.com
}

\begin{abstract}
The development of teaching materials especially on the subject of Al-Qur'an Hadith in Madrasah Ibtidaiyah is important to do. There are many creative things that a teacher can do to make learning the Al-Qur'an Hadith to be fun learning but all the basic competencies and indicators can be achieved. A teacher can take advantage of a variety of learning resources and make an integrated teaching material in one's learning. For the introduction of the hijaiyah letter as the earliest material in studying the Qur'an Hadith, teachers can utilize audio visual media as well as card games. Although various teaching materials are available and supported by a variety of media, without the support of teacher creativity, all is meaningless.
\end{abstract}

Keywords: Educator, Al-Qur'an Hadith

\begin{abstract}
Abstrak
Pengembangan bahan ajar khususnya pada mata pelajaran Al-Qur'an Hadis di Madrasah Ibtidaiyah penting untuk dilakukan. Banyak hal-hal yang kreatif yang dapat dilakukan guru untuk membuat pembelajaran Al-Qur'an Hadis menjadi pembelajaran yang menyenangkan namun semua kompetensi dasar maupun indikatornya dapat tercapai. Seorang guru dapat memanfaatkan berbagai sumber belajar dan menjadikan satu bahan ajar yang terpadu dalam satu pembelajaran. Untuk pengenalan huruf hijaiyah sebagai materi yang paling awal dalam mempelajari Al-Qur'an Hadis, guru dapat memanfaatkan media audio visual maupun berupa permainan kartu. Walaupun berbagai bahan ajar tersedia dan didukung oleh berbagai media, tanpa didukung oleh kreativitas guru, maka semua tidak berarti apa-apa.
\end{abstract}

Kata Kunci : Bahan Ajar, Al-Qur'an Hadis

\section{A. PENDAHULUAN}

Menjadi guru kreatif dan menyenangkan kini menjadi sebuah keharusan. Termasuk menjadi guru Pendidikan Agama Islam tentunya memiliki tantangan yang tidak sedikit. Menjadi guru Al-Qur'an merupakan hal yang istimewa. Hal ini pernah disabdakan oleh Rasulullah SAW dalam hadis yang diriwayatkan oleh Imam Bukhari. 


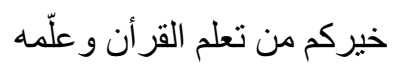

"Sebaik-baik kalian adalah yang belajar Al-Qur'an dan mengajarkannya”(H.R. Bukhari) ${ }^{1}$

Sebagaimana telah diketahui bahwa Al-Qur'an dan Hadis adalah sumber hukum utama umat Islam. Al-Qur'an dan hadis adalah rujukan utama umat Islam maka ini menjadi hal yang sangat penting untuk diajarkan kepada anak-anak sejak dini. Secara formal adanya mata pelajaran Al-Qur'an Hadis di Madrasah Ibtidaiyah memiliki tujuan² yaitu:

1. Memberikan kemampuan dasar kepada peserta didik dalam membaca, menulis, membiasakan, dan menggemari membaca Al-Qur'an dan Hadis.

2. Memberikan pengertian, pemahaman, penghayatan isi kandungan ayat-ayat Al-Qur'an hadis melalui keteladanan dan pembiasaan.

3. Membina dan membimbing perilaku peserta didik dengan berpedoman pada isi kandungan ayat Al-Qur'an dan Hadis.

Sebagai guru yang professional setidaknya guru harus memahami tujuan-tujuan tersebut di atas. Maka dalam mengajar Al-Qur'an dan hadis guru harus kreatif dan memahami tingkat psikologis peserta didik. Bahan ajar juga dapat diperoleh dari berbagai sumber, bahkan seorang guru yang kreatif dapat membuat bahan ajar sendiri berdasarkan hasil seleksi dari berbagai sumber. Bahan ajar yang diperoleh bisa dikonkretkan lagi berupa membuat alat peraga dan menerapkan strategi pembelajaran yang aktif, kreatif, inovatif, efektif dan menyenangkan.

\section{B. PENGERTIAN SUMBER BELAJAR DAN BAHAN AJAR}

Sebelum membahas tentang bahan ajar, kita perlu mengetahui dahulu tentang sumber belajar. Sumber belajar adalah rujukan, objek dan/ atau bahan yang digunakan untuk kegiatan pembelajaran. ${ }^{3}$ Menurut Association for Educational Communications and Technology (AECT, 1977), sumber belajar adalah segala sesuatu atau daya yang dapat dimanfaatkan oleh guru, baik secara terpisah maupun dalam bentuk gabungan, untuk kepentingan belajar mengajar dengan tujuan meningkatkan efektivitas dan efisiensi tujuan pembelajaran. Dengan demikian maka

\footnotetext{
${ }^{1}$ Al-Bukhāri, Shahih Bukhāri, "Kitab Faḍa’il Qur'an” (Amman Jordan: Bait Al Afkar Ad Dauliayah,1998), hlm. 587. Hadis diriwayatkan oleh Uṡman ra.

${ }^{2}$ Peraturan Menteri Agama Republik Indonesia No. 912 Tahun 2013 Tentang Kurikulum Madrasah 2013 Mata Pelajaran Pendidikan Agama Islam dan Bahasa Arab

${ }^{3}$ Masnur Muslich, KTSP Dasar Pemahaman dan Pengembangan, cet. ke-5 (Jakarta: PT. Bumi Aksara, 2009), hlm. 30.
} 
sumber belajar juga diartikan sebagai segala tempat atau lingkungan sekitar, benda, dan orang yang mengandung informasi dapat digunakan sebagai wahana bagi peserta didik untuk melakukan proses perubahan tingkah laku. ${ }^{4}$

Dari pengertian tersebut maka sumber belajar dapat dikategorikan sebagai berikut ${ }^{5}$ :

1. Tempat atau lingkungan alam sekitar yaitu dimana saja seseorang dapat melakukan belajar atau proses perubahan tingkah laku maka tempat itu dapat dikategorikan sebagai tempat belajar yang berarti sumber belajar, misalnya perpustakaan, pasar, museum, sungai, gunung, tempat pembuangan sampah, kolam ikan dan lain sebagainya.

2. Benda yaitu segala benda yang memungkinkan terjadinya perubahan tingkah laku bagi peserta didik, maka benda itu dapat dikategorikan sebagai sumber belajar. Misalnya situs, candi, benda peninggalan lainnya.

3. Orang yaitu siapa saja yang memiliki keahlian tertentu di mana peserta didik dapat belajar sesuatu, maka yang bersangkutan dapat dikategorikan sebagai sumber belajar. Misalnya guru, ahli geologi, polisi, dan ahli-ahli lainnya.

4. Bahan yaitu segala sesuatu yang berupa teks tertulis, cetak, rekaman elektronik, web, dan lain-lain yang dapat digunakan untuk belajar.

5. Buku yaitu segala macam buku yang dapat dibaca secara mandiri oleh peserta didik dapat dikategorikan sebagai sumber belajar. Misalnya buku pelajaran, buku teks, kamus, ensiklopedi, fiksi dan lain sebagainya.

6. Peristiwa dan fakta yang sedang terjadi, misalnya peristiwa kerusuhan, peristiwa bencana, dan peristiwa lainnya yang guru dapat menjadikan peristiwa atau fakta sebagai sumber belajar.

Sumber belajar akan menjadi bermakna bagi peserta didik maupun guru apabila sumber belajar diorganisir melalui satu rancangan yang memungkinkan seseorang dapat memanfaatkannya sebagai sumber belajar. Jika tidak maka tempat atau lingkungan alam sekitar,

\footnotetext{
${ }^{4}$ Direktorat Pembinaan Sekolah Menengah Atas, Panduan Pengembangan bahan Ajar, (Jakarta: Dirjen. Manajeman Pendidikan Dasar dan Menengah Depdiknas, 2008), hlm. 5

${ }^{5}$ Ibid.,
} 
benda, orang, dan atau buku hanya sekedar tempat, benda, orang atau buku yang tidak ada artinya apa-apa.

Dari uraian tentang pengertian sumber belajar di atas, dapat disimpulkan bahwa bahan ajar merupakan bagian dari sumber belajar. Kumpulan sumber belajar yang relevan dengan materi yang akan diajarkan lalu dikumpulkan. Hasil pengumpulan materi dari berbagai sumber belajar itu yang disebut bahan ajar. Bahan ajar pada dasarnya merupakan segala bahan (baik itu informasi, alat maupun teks) yang disusun secara sistematis yang menampilkan sosok yang utuh dari kompetensi yang akan dikuasai peserta didik dan digunakan dalam proses pembelajaran dengan tujuan untuk perencanaan dan penelaahan implementasi pembelajaran. ${ }^{6}$ Secara sederhana, bahan ajar adalah segala bentuk bahan yang digunakan untuk membantu guru/instruktor dalam melaksanakan kegiatan belajar mengajar. Bahan yang dimaksud bisa berupa bahan tertulis maupun bahan tidak tertulis.

Pengembangan bahan ajar menjadi sangat penting karena para guru umumnya hanya bergantung pada buku paket buatan penerbit saja tanpa memperhatikan sumber ajar lainnya. Untuk membuat siswa antusias terhadap pembelajaran yang dilakukan oleh guru, maka guru harus kreatif dalam mengembangkan bahan ajar. Guru harus kreatif karena ia tidak hanya bertindak sebagai pemberi informasi saja, namun juga sebagai fasilitator dan mitra belajar bagi peserta didik. Guru harus memberikan layanan dan kemudahan belajar (facilitate learning) kepada seluruh peserta didik agar mereka dapat belajar dalam suasana yang menyenangkan, gembira, penuh semangat, tidak cemas dan berani mengungkapkan pendapat secara terbuka. ${ }^{7}$

\section{PENGEMBANGAN BAHAN AJAR AL-QUR'AN HADIS}

Saat ini guru dapat dengan mudah memperoleh buku elektronik dari internet yaitu buku pegangan guru mata pelajaran Al-Qur'an Hadis kelas I Madrasah Ibtidaiyah. Ini pun merupakan salah satu bahan ajar guru. Pada salah satu materi Al-Qur'an Hadis kelas 1 semester ganjil misalnya, kompetensi inti dan kompetensi dasarnya dapat dilihat sebagai berikut. ${ }^{8}$

\footnotetext{
${ }^{6}$ Andi Prastowo, Pengembangan Bahan Ajar Tematik Tinjauan Teoritis dan Praktik, (Jakarta: Kencana Prenada Media, 2014), hlm. 138.

${ }^{7}$ E. Mulyasa, Pengembangan dan Implementasi Kurikulum 2013, cet. ke-2 (Bandung: PT. Remaja Rosdakarya, 2013), hlm. 42.

${ }^{8}$ Peraturan Menteri Agama Republik Indonesia No. 912 Tahun 2013 Tentang Kurikulum Madrasah 2013 Mata Pelajaran Pendidikan Agama Islam dan Bahasa Arab
} 


\begin{tabular}{|l|l|l|}
\hline No & \multicolumn{1}{|c|}{ Kompetensi inti } & Kompetensi dasar \\
\hline 1 & $\begin{array}{l}\text { Menerima dan menjalankan ajaran } \\
\text { agama yang dianutnya. }\end{array}$ & $\begin{array}{l}\text { Meyakini bahwa mempelajari Al- } \\
\text { Qur'an adalah ibadah }\end{array}$ \\
\hline 2 & $\begin{array}{l}\text { Memiliki perilaku jujur, disiplin, } \\
\text { tanggung jawab, santun, peduli, dan } \\
\text { percaya diri dalam berinteraksi dengan } \\
\text { keluarga, teman, dan guru. }\end{array}$ & $\begin{array}{l}\text { Memiliki perilaku mencintai Al- } \\
\text { Qur'an dalam kehidupan }\end{array}$ \\
\hline 3 & $\begin{array}{l}\text { Memahami pengetahuan faktual dengan cara } \\
\text { mengamati mendengar, melihat, } \\
\text { membaca dan menanya berdasarkan rasa ingin } \\
\text { tahu tentang dirinya, makhluk } \\
\text { cipta an Tuhan dan kegiatannya, dan benda- } \\
\text { benda yang dijumpainya di rumah } \\
\text { dan di sekolah. }\end{array}$ & $\begin{array}{l}\text { 1. } \begin{array}{l}\text { Mengetahui huruf-huruf } \\
\text { hijaiyah dan tanda bacanya } \\
\text { (fathah, kasrah dan dhammah). } \\
\text { Membaca huruf-huruf hijaiyah } \\
\text { sesuai makhraj dan tanda } \\
\text { bacanya (fathah, kasrah dan } \\
\text { dhammah). }\end{array} \\
4\end{array}$ \\
$\begin{array}{l}\text { Menyajikan pengetahuan faktual dalam bahasa } \\
\text { yang jelas dan logis, dalam } \\
\text { karya yang estetis, dalam gerakan yang } \\
\text { mencerminkan anak sehat, dan dalam } \\
\text { tindakan yang mencerminkan perilaku anak } \\
\text { beriman dan berakhlak mulia. }\end{array}$ & $\begin{array}{l}\text { Membaca huruf-huruf hijaiyah } \\
\text { sesuai makhraj dan tanda bacanya } \\
\text { (fathah, kasrah dan dhammah). }\end{array}$ \\
\hline
\end{tabular}

Jika merujuk pada buku pegangan guru mata pelajaran Al-Qur'an Hadis kelas 1 kurikulum 2013 nampaknya lebih terlihat seperti formalitas. Jika memang ini adalah materi yang diberikan kepada anak yang sudah mengenal huruf hijaiyah maka pembelajaran ini adalah membuat anak senang untuk belajar huruf hijaiyah. Akan terasa berbeda jika siswa yang diajar sama sekali belum pernah mengenal huruf hijaiyah.

Mengenalkan huruf hijaiyah merupakan hal pertama yang diajarkan seseorang guru ketika mengajarkan membaca Al-Qur'an. Mengajarkan siswa membaca huruf hijaiyah dengan benar tidak sesederhana apa yang dipikirkan. Jumlah huruf hijaiyah ada 29 jika "lam alif" tidak dimasukkan. Di dalam buku pedoman tersebut ada dua hal yang diminta yaitu membaca huruf aslinya dan membaca huruf hijaiyah tunggal dengan tiga macam harokat sekaligus yaitu fathah, kasrah, dan dhommah.

Tentunya hal ini sangat memberatkan bagi siswa untuk menghafalkannya dalam waktu singkat. KH. Asad Humam sebagai penemu metode Iqro' hanya menerapkan huruf hijaiyah tunggal berharokat fathah hanya di jilid satu dan buku Iqro' jilid satu tersebut terdiri dari 35 
halaman. Di jilid satu tersebut anak tidak diperkenalkan hurufnya seperti "alif" namun langsung pada huruf berharokat fathah ( $a, b a, t a, t s a, j a$ dan seterusnya). ${ }^{9}$. Tentunya untuk menguasai huruf tersebut dibutuhkan banyak pertemuan.

Mengacu pada teori untuk mengembangkan bahan ajar maka yang harus ditempuh $\operatorname{adalah}^{10}$ :

1. Menyiapakan KI/ SK dan KD untuk melakukan analisis kebutuhan bahan ajar

2. Menuliskan indikator pencapaiannya

3. Menuliskan materi pembelajarannya

4. Menentukan sumber belajarnya

5. Menentukan jenis bahan ajar yang akan dibuat

6. Menyusun peta bahan ajar

Berikut ini contoh analisis pengembangan bahan ajar Al-Qur'an Hadis

Mata Pelajaran : Al-Qur'an Hadis

Kelas : I

Semester $\quad: 1$ (Satu)

KI 3 : Memahami pengetahuan factual dengan cara mengamati, mendengar, melihat, membaca dan menanya berdasarkan rasa ingin tahu tentang dirinya, makhluk ciptaan Tuhan dan kegiatannya, dan benda-benda yang dijumpainya di rumah dan di sekolah.

Peta bahan ajar Al-Qur'an Hadis :

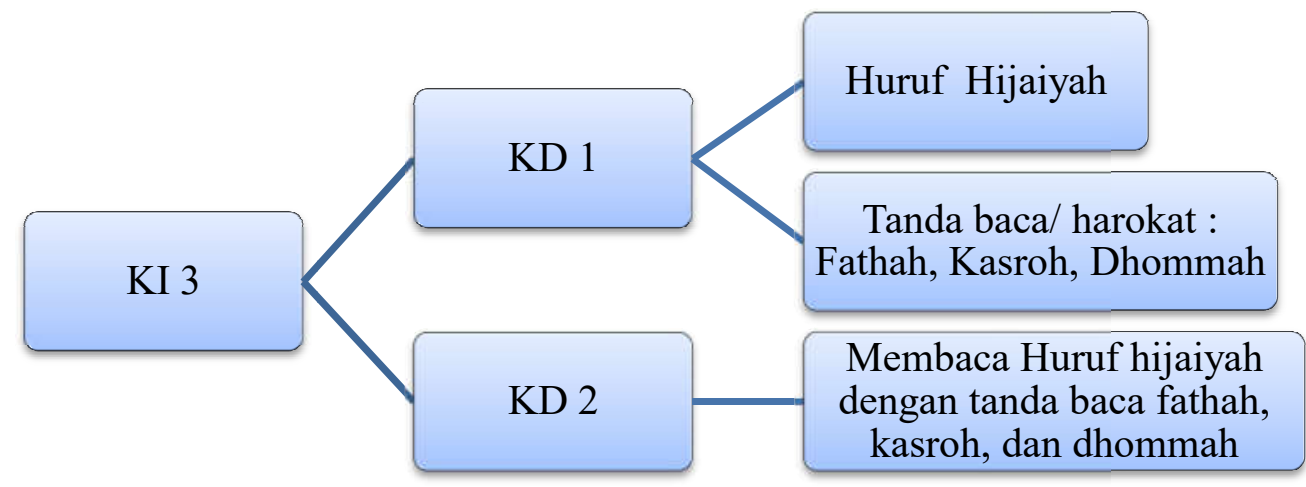

\footnotetext{
${ }^{9}$ Mangun Budianto, Prinsip-prinsip Metodologi Buku Iqro’ (Yogyakarta: Team Tadarus AMM, 1995), hlm. 10 .

${ }^{10}$ Direktorat Pembinaan SMA, Petunjuk Teknis Pengembangan Bahan Ajar SMA, (Jakarta: Kementerian Pendidikan Nasional, 2010), hlm. 31.
} 


\begin{tabular}{|c|c|c|c|c|c|}
\hline $\begin{array}{l}\text { Kompetensi } \\
\text { Dasar }\end{array}$ & Indikator & $\begin{array}{l}\text { Materi } \\
\text { pembelajaran }\end{array}$ & $\begin{array}{l}\text { Kegiatan } \\
\text { pembelajaran }\end{array}$ & $\begin{array}{l}\text { Sumber } \\
\text { Belajar }\end{array}$ & $\begin{array}{l}\text { Jenis bahan } \\
\text { Ajar }\end{array}$ \\
\hline $\begin{array}{l}\text { 1. Mengetah } \\
\text { ui huruf- } \\
\text { huruf } \\
\text { hijaiyah } \\
\text { dan tanda } \\
\text { bacanya } \\
\text { (fathah, } \\
\text { kasrah dan } \\
\text { dhammah) } \\
\text {. }\end{array}$ & $\begin{array}{l}\text { 1. Siswa } \\
\text { mampu } \\
\text { menyebutk } \\
\text { an nama } \\
\text { huruf- } \\
\text { huruf } \\
\text { hijaiyah } \\
\text { 2. Siswa } \\
\text { mampu } \\
\text { menyebutk } \\
\text { an tanda } \\
\text { baca } \\
\text { harokat } \\
\text { fathah, } \\
\text { kasrah dan } \\
\text { dhommah } \\
\text { Siswa } \\
\text { mampu } \\
\text { membaca } \\
\text { huruf- } \\
\text { huruf } \\
\text { hijaiyah } \\
\text { sesuai } \\
\text { makhraj } \\
\text { dan tanda } \\
\text { bacanya } \\
\text { (fathah, } \\
\text { kasrah dan } \\
\text { dhammah). }\end{array}$ & 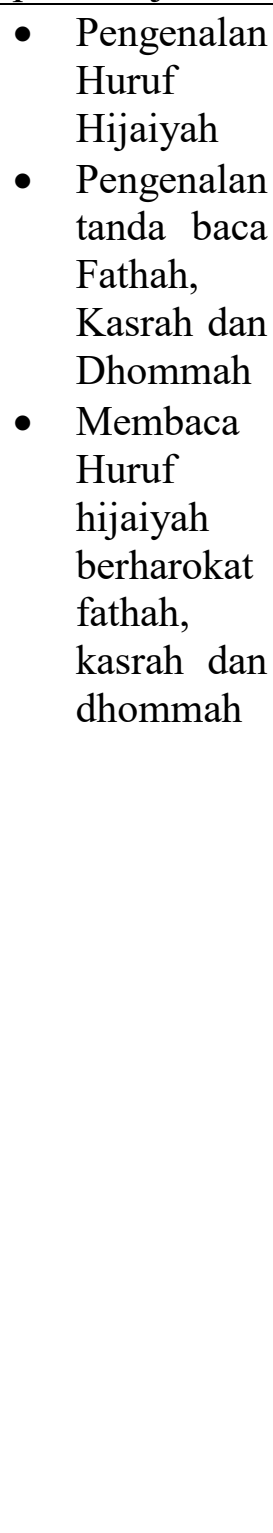 & 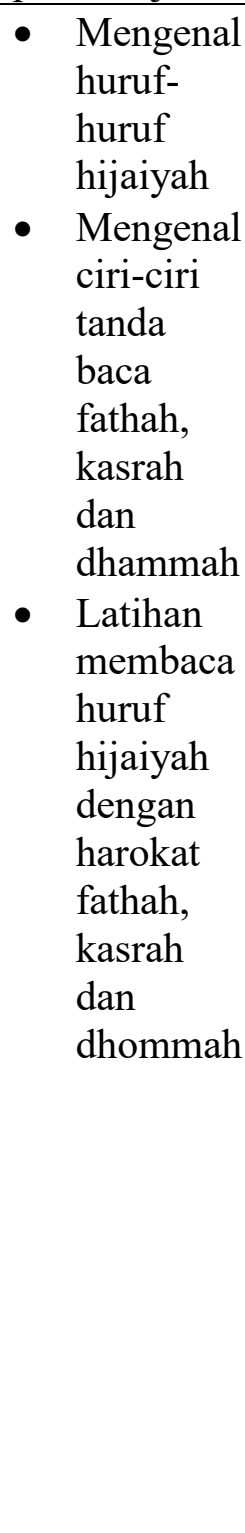 & $\begin{array}{l}\text { Buku Guru } \\
\text { dan Siswa } \\
\text { Buku Iqro, } \\
\text { Jilid 1 } \\
\text { Buku Ummi } \\
\text { jilid 1 }\end{array}$ & $\begin{array}{l}\text { Slide } \\
\text { Kartu }\end{array}$ \\
\hline
\end{tabular}

Setelah melihat peta bahan ajar dan analisis kebutuhan bahan ajar, barulah guru membuat bahan ajar. Jika memungkinkan untuk mencapai target sebagaimana yang diharapkan oleh kompetensi dasar maka ada beberapa langkah yang bisa ditempuh dan tentunya tidak dapat dicapai dalam sekali tatap muka. Guru bisa mengajarkan huruf hijaiyahnya sekaligus membaca dengan harokat fathah, kasroh dan dhommah. Misalnya tatap muka pertama guru menargetkan 
siswa mengetahui dan menghafal "Alif" sampai "zai". Pada tatap muka kedua dilanjutkan dari huruf "sin" sampai "Qaf”. Dan pada tatap muka ketiga dari huruf "Kaf" sampai “ya:.

Untuk alat peraga, guru bisa membuat slide, atau membuat kartu. Guru juga bisa menggunakan lagu untuk menghafal huruf hijaiyah. Namun menggunakan lagu bisa membuat siswa menghafal lagunya namun jika hurufnya di acak siswa belum tentu bisa membacanya. Artinya masih diperlukan waktu juga untuk masuk dalam memori siswa. Namun hal ini patut dicoba untuk membuat pembelajaran menjadi menyenangkan.

Alat-alat yang diperlukan dalam membuat bahan ajar yang berupa kartu dapat diperoleh dengan membuat sendiri atau membeli yang sudah berupa produk jadi. Atau guru bisa mengkombinasikan lagu, slide, dan kartu. Jika satu kartu tertulis satu huruf maka untuk huruf hijaiyah saja terdiri dari 30 kartu. Jika ditambah dengan kartu huruf yang berharokat "fathah", "kasrah" dan "dhammah" maka setidaknya diperlukan 120 kartu yang harus dipersiapkan oleh guru. Guru juga harus membuat pola latihan dengan mengacak huruf hijaiyah. Jika di buku paket pegangan guru tertulis "Alif, " $a$ ", " $i$ ", " $u$ ” maka guru harus bisa melatih siswa untuk membaca, misalnya: “alif”, “i”, “a”, “u”; “u”, “i”, “a”, “a”, “u”, “i” “alif”.

Di dalam buku siswa Al-Qur'an Hadis kelas I yang diterbitkan oleh Kementerian Agama tahun 2014, dalam materi pembelajarannya hanya tercantum sebagaimana di bawah nni $^{11}$.

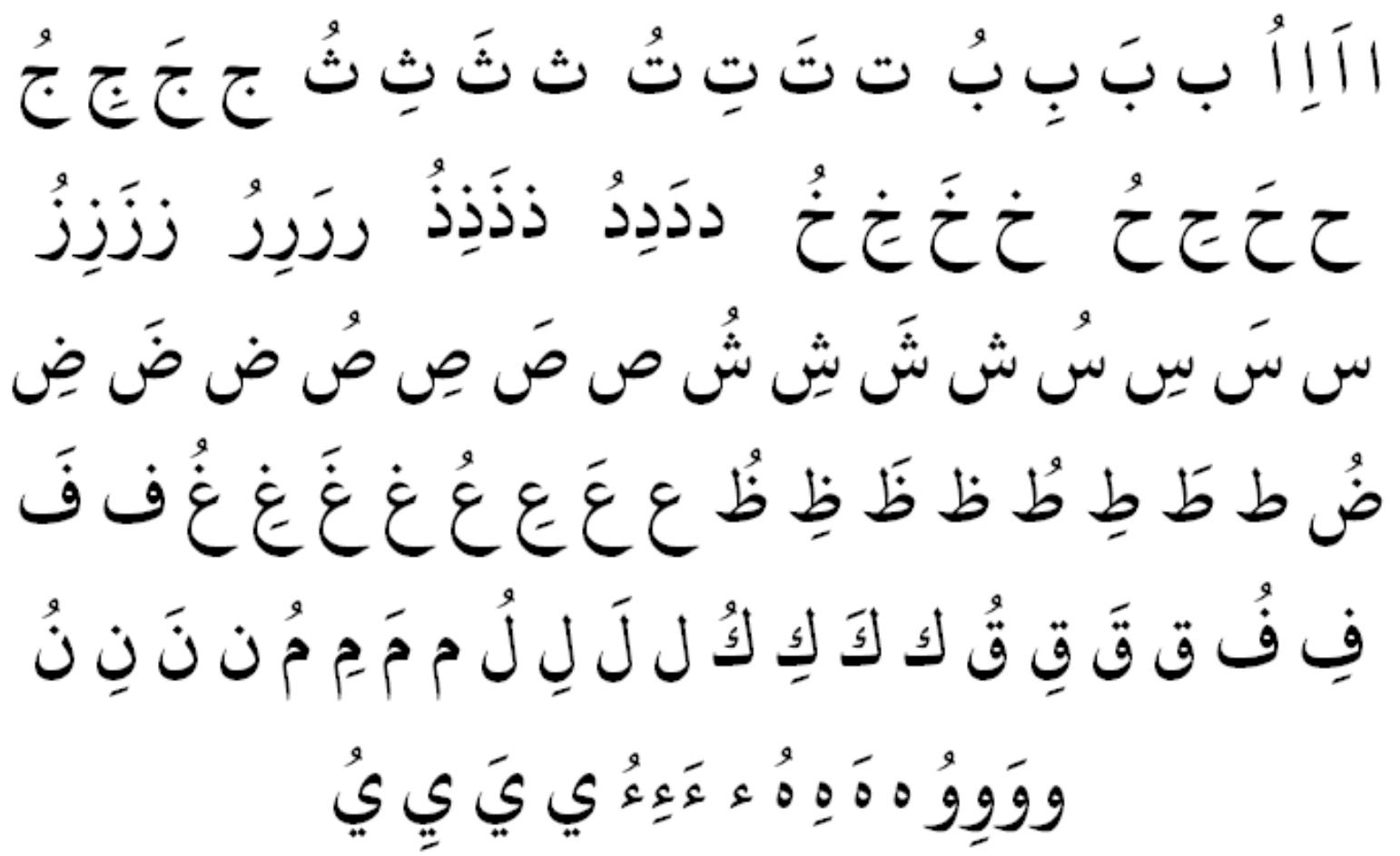

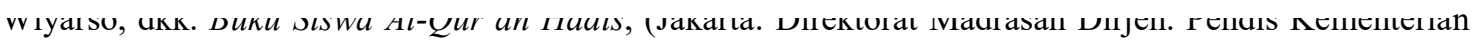
Agama RI, 2014), hlm. 4 
Dalam tulisan ini, penulis hanya memberikan contoh atau sampel berupa pertemuan pertama dimana siswa diharapkan bisa menghafalkan huruf "alif" dan "zai", namun penulis hanya mencontohkan "alif" dan " $b a$ " saja. Berikut ini contoh bahan ajar tatap muka pertama:

1. Guru mengajak siswa menyaksikan video lagu huruf hijaiyah dan bernyanyi bersama.

2 .

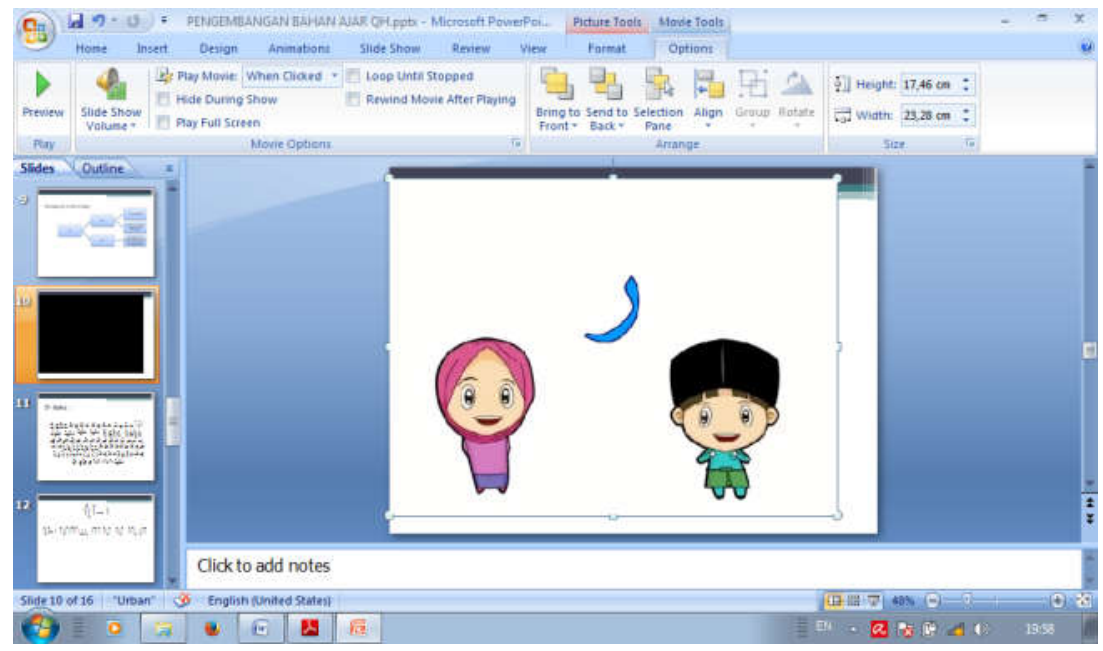

Gambar 1. Tampilan lagu huruf hijaiyah

3. Guru menampilkan slide power Point

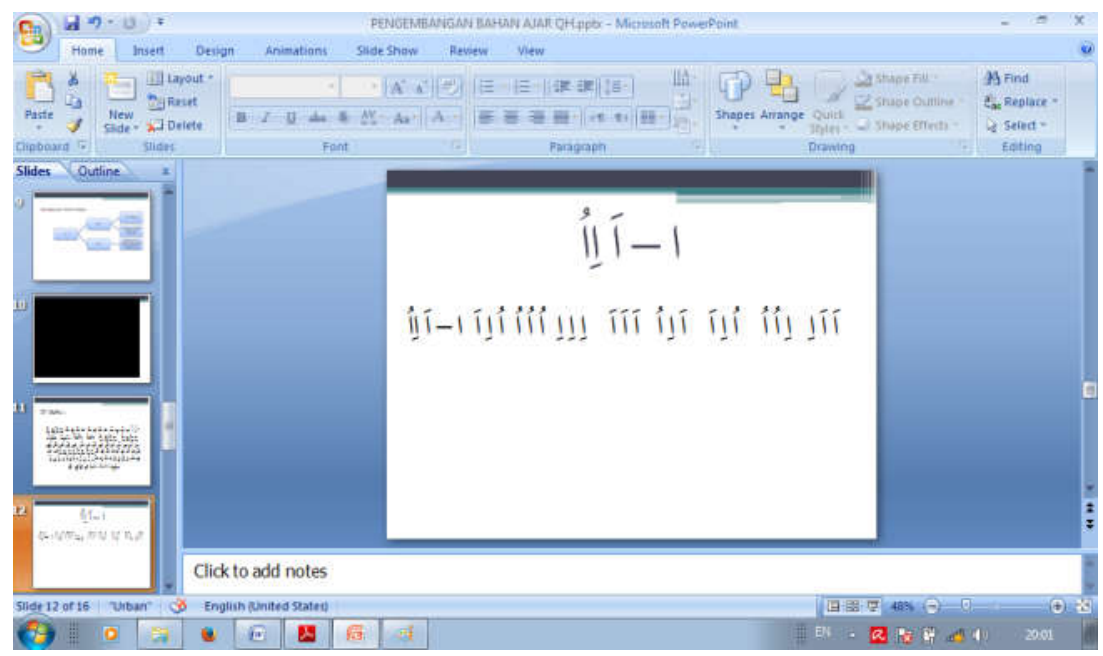

Gambar 2. Materi pengenalan Huruf "Alif" 


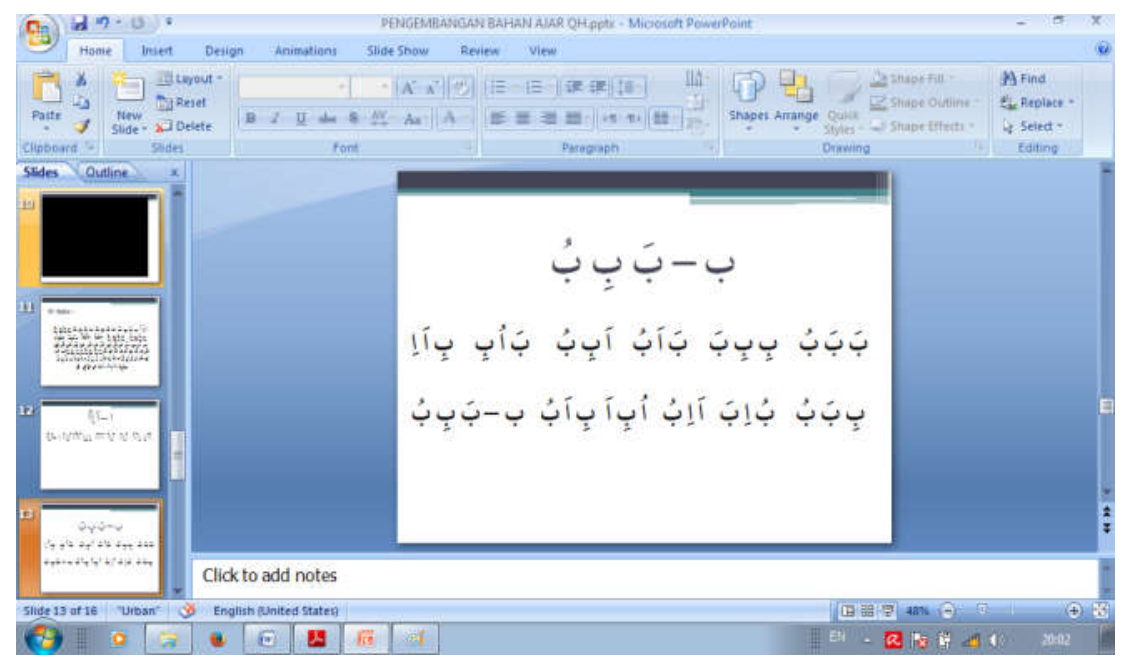

Gambar 3. Materi pengenalan Huruf " $B a$ "

Tulisan dalam slide :

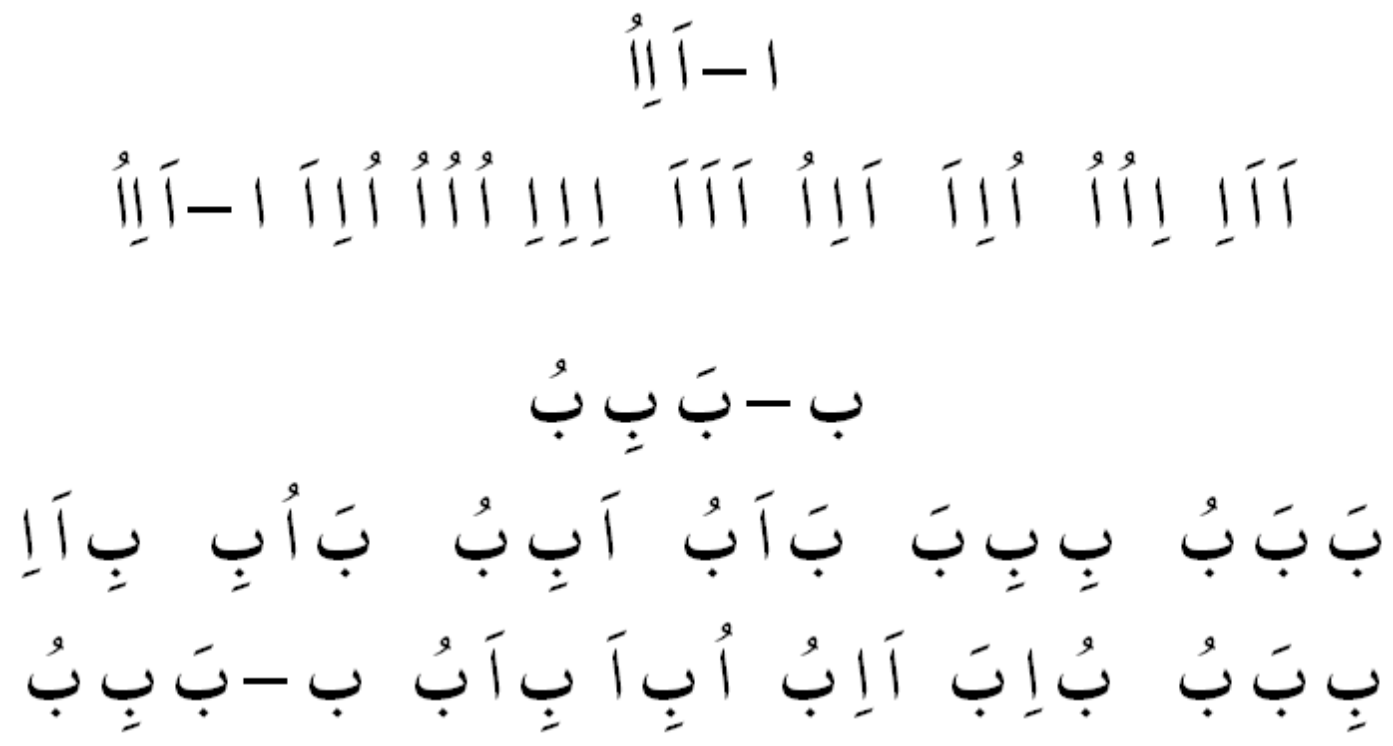

4. Guru membuat kuis dengan menggunakan kartu-kartu huruf hijaiyah

5. Guru memberikan apresiasi kepada seluruh siswa

Sebelum guru menutup pembelajaran, guru dapat memberikan motivasi karena pertemuan selanjutnya siswa akan mempelajari huruf-huruf hijaiyah berikutnya sebagaimana target yang telah dibuat oleh guru. Meskipun guru dapat membuat bahan ajar sedemikian rupa namun tidak ditunjang oleh kreativitas guru dalam mengemasnya bersama strategi pembelajaran menjadi suatu kesatuan, maka media apapun menjadi tidak bermakna. 


\section{PENUTUP}

Ketika guru dituntut lebih profesional maka berbagai upaya harus dilakukan untuk meningkatkan kualitasnya salah satunya ialah mengembangkan bahan ajar. Dalam mengembangkan bahan ajar banyak langkah-langkah yang harus ditempuh oleh guru hingga ia menentukan bahan ajar apa yang akan digunakan. Dalam mengembangkan bahan ajar Al-Qur'an Hadis, guru dapat menggunakan bahan ajar modul latihan sebagai pegangan siswa, slide, kartu, file lagu dan sebagainya. Bahan ajar yang begitu banyak juga perlu didukung oleh kreativitas guru untuk mengemasnya dalam satu kesatuan bersama dengan strategi pembelajaran dan unsurunsur lainnya. 


\section{DAFTAR PUSTAKA}

Al-Bukhāri, Shahih Bukhāri, "Kitab Faḍa'il Qur'an" (Amman Jordan: Bait Al Afkar Ad Dauliayah,1998), hlm. 587. Hadis diriwayatkan oleh Usंman ra.

Budianto, Mangun, Prinsip-prinsip Metodologi Buku Iqro', Yogyakarta: Team Tadarus AMM, 1995

Direktorat Pembinaan Sekolah Menengah Atas, Panduan Pengembangan bahan Ajar, Jakarta: Dirjen. Manajeman Pendidikan Dasar dan Menengah Depdiknas, 2008

Direktorat Pembinaan SMA, Petunjuk Teknis Pengembangan Bahan Ajar SMA, Jakarta: Kementerian Pendidikan Nasional, 2010

Mulyasa, E., Pengembangan dan Implementasi Kurikulum 2013, cet. ke-2, Bandung: PT. Remaja Rosdakarya, 2013

Muslich, Masnur, KTSP Dasar Pemahaman dan Pengembangan, cet. ke-5, Jakarta: PT. Bumi Aksara, 2009

Peraturan Menteri Agama Republik Indonesia No. 912 Tahun 2013 Tentang Kurikulum Madrasah 2013 Mata Pelajaran Pendidikan Agama Islam dan Bahasa Arab

Prastowo, Andi, Pengembangan Bahan Ajar Tematik Tinjauan Teoritis dan Praktik, Jakarta: Kencana Prenada Media, 2014

Wiyarso, dkk. Buku Siswa Al-Qur'an Hadis, Jakarta: Direktorat Madrasah Dirjen. Pendis Kementerian Agama RI, 2014 